\title{
WHY DO HUNGARIAN CIVIL ORGANISATIONS NOT LIKE TO CO-OPERATE?
}

\author{
KRISZTINA KÓBOR ${ }^{1}$
}

\begin{abstract}
This essay is based upon the fact, backed by research, that co-operation today between civil organisations in Hungary is incidental (KSH 2003, Bartal, Kákai and Szabó 2005, Nárai 2007). Despite this, the question to which we rarely or never receive an answer is which theoretical and practical causes can be specified. The author therefore attempts herein to outline the socio-historic, welfare-politic and practical motive systems which provide a basis for the nonco-operative practice of civil organisations, and based on which, suggest more effective programs and interventions that can be implemented in order to support collaborative practice.
\end{abstract}

KEYwORDS civil society, civil organisations, co-operation

\section{INTRODUCTION}

There are those who do not believe in the idea of civil society.

According to Margaret Thatcher or Václav Klaus, there is no such thing as civil society - there are only individuals and families, between who free market relations create a connection. Klaus says that collectivism and the suspicious "third passenger"-ideology hide behind the notion of civil society (Miszlivetz 2001). There are those who do believe in the idea of civil society.

According to the Yanomamo Indians, it is important to show their guests their quiver, in which the arrows of their previous guests are held. The guests themselves give one of their arrows with their personal signs as a present to the host. In this way everybody can see at once who the host can rely on and what social network he belongs to (Csányi 1999).

1 Krisztina Kóbor is PhD student at the Doctoral School of Regional and Economic Sciences of the Széchenyi István University; e-mail: kobor.kriszta@t-online.hu 
Beyond the Yanomamo Indians there have been other societies - even in ancient times - which believed in the notion of civil society. The expression itself, as so many other things, has its roots in antiquity. The direct equivalent of the term in Latin is "societas civilis", and in Ancient Greek is "politike koinona". In antiquity this meant some kind of a political society where active citizens could shape politics, and one of its important characteristics was to put the common good in front of private interests.

Many have already proven in various ways that civil/non-profit organisations ${ }^{2}$ do not co-operate in today's Hungary, or rather, their co-operation is incidental (KSH 2003, Bartal, Kákai and Szabó 2005, Nárai 2007). Many have argued for the necessity of co-operation because collaboration would involve many advantages for all participants in the long run (Kákai 2005, Kassó 2006, Sebestyén 2005 and 2009).

At the same time, we receive answers only rarely and with difficulty to the questions of what the obstacles are for incidental or total lack of collaboration within the civil sphere and why collaborations started from state or grassroots extinguish after a while, or are not established at all. This essay attempts to reveal and sum up the socio-theoretical, historical, welfare-political and practical motives which lead to an obstruction of co-operation within civil society (with each other or with organisations from various sectors).

As regards the situation within the civil sphere, based on the data collection of KSH (The Central Statistical Office in Hungary) in the year 2003, we can say that $37 \%$ of civil organisations are members of some kind of regional or professional association, civil forum or round table. It also turns out that cooperation within the sector is more frequent than the connection of organisations with different goals based on area or regional communities (KSH 2005, 22).

Bartal, Kákai and Szabó arrived at a similar conclusion in research supported by the National Civil Basic Program, carried out within the framework of the Civil Academy of The End of the Century (Bartal A. - Kákai L. - Szabó I. 2005, 85-87) (Kákai 2005).

Basically, two forms of relations can be observed between civil organisations: regional and professional. Regional relationships form primarily on a county basis; these organisations do not think either in terms of small areas or on a regional scale - they concentrate first on their local environment. All this

2 The use of the expression varies, and the expressions 'civil', 'non-profit', 'NGO,' etc. are mostly used as synonyms. Nárai (2007) tries to clear up the confusing use of the expressions and defines social self-organisations (= civil sphere) within the notion of civil society. According to Nárai, the non-profit sector belongs to the civil sphere. In Nárai's approach, the non-profit sector includes the civil non-profit sector and the close-to-state non-profits. In this essay I consider the above expressions to be synonyms without discussing the problem of definitions. 
is determined in a certain way by the existing (political and civil network) system of organisations and by a network of umbrella associations. The research of Bartal, Kákai and Szabó (2005) confirmed the above statements on a nationwide level. On the basis of their research, it turned out that, following national relations, mostly local ones were established by the organisations, and the number of links at a county-level was far behind.

Of course there are several programs and organisations in Hungary which organise the relationships of the civil sphere, so one could imagine that the networking of the sphere - the finding and promoting of their points of contact - had been sorted out. In practice, however, most organisations bring up the problem that the relations-organisers, although one cannot deny that they provide services (e.g., legal, tender application, counselling, etc.) for smaller organisations, and thereby strengthen them, are mostly established, managed from (and therefore influenced from) above (e.g. CISZOK - Service Centre for Civil Organisations), so they do not primarily serve the demands and needs of the sphere and are unable to represent its interests.

The situation is complicated by the fact that duplicate systems exist in Hungary for supporting civil connections: CISZOK, NIOK, Kútfö (as part of the ROP), TESZ, etc. All these are weakening the effectiveness and efficiency of co-operation, not to mention consuming resources and generating competition with each other. The organisations established for supporting relations are therefore rivals to each other in a paradoxical way. The biggest problems with these organisations are that they are operated from above, and respectively, the fear of civil organisations of the fact that the goals defined at the moment as co-operation could be replaced by a hierarchic organisation with an authoritarian character which would not have as a focus the maintenance of relationships. Sebestyén (2009) suggests for this reason the establishment of an organisation which supports relations between civil organisations and provides a representation of interest for civil organisations and emphasises organisation from below, and in the view of them, legitimacy. This is the idea of the Civil Chamber, whose members would be elected from among the representatives of civil organisations. The suggestion would probably solve a lot of problems (representation of interests, organisation from below, simplifying the connection-building system, eliminating the competitive situation), but on the other hand initiatives which are not institutionalised and come from below (informal communities, from the formulation of Tönnies and others) would not have a place there either, or that the civil organisation that does not register to be elected could not be elected, even if it was fit to perform the tasks. According to Kákai (2005), such an institution would assist the engagement of civil organisations with the preparation of local 
government decisions - and therefore with establishing other co-operation or through the strengthening of their lobby activities - if organisations were able to organise themselves from below.

The survey of Kútfő on demand, carried out in Western Transdanubia in 2006, provided similar results. Out of 328 questionnaires sent out, only 52 were sent back. From the small areas of Kapuvár, Lenti, Pannonhalma, Sopron-Fertőd and Tét, no questionnaires were sent back.

The research surveyed the resources and capacities of the organisations: their national and international partnering experience, their experience regarding project development, professional counselling, mentoring and development skills, their willingness to network and their demands regarding the Kútfö network.

According to the results of the research, the most significant barriers to partnering are that it is difficult to harmonise the different organisational cultures and that they only know a couple of organisations potentially suitable for partnering. Most organisations say that providing information on a regular basis and organising regular meetings would increase better partnering. Almost half of the respondent organisations have significant experience as project hosts and in participating in the working-out and realising of projects concerning several sectors. Of the respondents, $89 \%$ would participate in the Kútfó network and 96 percent would use counselling and professional support with the working-out and realisation of their project ideas. For these organisations, it is important that the network introduces and disseminates recent organisational models and introduces long-standing and creative examples (Kútfö Demand Survey, 2006). At the same time, it is important experientially that the Kútfö program itself commenced (as part of the ROP program) in 2001, and again in 2006, with the purpose of establishing a network consolidating significant forces. Both times it started with pushing and initiating from above and ended both times with atrophy and termination.

The basic moral of the research into the relationships of the civil organisations is that the established political and civil organisation system determines the willingness of the organisations to co-operate, and if it does not inspire cooperation then the determination related to it is decreases as well.

Creating a willingness to co-operate from above and below has therefore failed in today's civil sphere in Hungary for the time being. The answer to the question "Why?" has to be found in theories linked to the civil sphere, and of course in operating civil organisations.

Therefore, in the next three parts of my paper I try to investigate the deep and general theoretical and practical causes (not limited only to those already mentioned) for the collaboration gap within the civil sector. 


\section{MOTIVE SYSTEM NO. 1: SEPARATION OF THE ECONOMIC, POLITICAL AND SOCIAL SPHERES}

In my approach, the reason for the theoretical background of the cooperational gaps within the contemporary civil sector in Hungary can be found, first of all, in the separation, and later estrangement, of the economical, political and social spheres from each other.

According to Hobbes' social contract theory (1970), the natural state is a war of each individual against every other individual. Civil society is the counterpart where - based on rights - both the leaders and the controlled are bound by laws included in the social contract. Hobbes, however, makes it clear at the beginning of his work that he uses the notions of 'commonwealth', 'state' and the Latin 'civitas' as synonyms, so his theory is not, foremost, a theory of civil society in today's sense, but one of social theories. Farkas $(2007,11)$ remarks that, according to Hobbes, "the state encircles the human crowd like an incubator; in its artificial climate, this crowd, which is raw and shapeless in its natural state, is able to start to take shape and to structure according to contracts and representative instructions, until the roles needed for these slowly confirm and the body becomes an organism able to lead an independent life, and it wakes up to it in due course."

The theory of social contract stands up in many societies (England, Germany, Austria, Sweden, etc.); Hankiss (2010), however, in his latest essay, deals exactly with the idea that contracts shaped according to the interpretation of Hobbes are not valid in today's society in Hungary, because for this to happen one would need strong and autonomous civil organisations (and citizens to make them up) - among other things - which is not a given in contemporary Hungarian society.

The first intellectual to hold that civil society is independent from the state, although living in symbiosis with it, was Hegel (1977). He says that civil society is purely a social contact and system of exchange that breaks away from governance and the public limelight. Hegel first coined this notion, having used it in 1821.

Also according to the interpretation of Glózer $(1999,71)$, the state equals politics, and she draws one's attention to the idea that it is necessary to separate the civil sphere from politics; that is, from the state: “... in speaking of civil society they are referring to the "web woven around politics", standing for the network of relationships between civil organisations and institutions outside and around the state."

Marx (1962) narrowed down the notion - and by doing so diverted it to some extent into a dead-end - when he associated civil society with bourgeois 
society and regarded only economic life as a stage for the notion in which everybody chases their own selfish interests and becomes alienated from their human potential and from their environment.

The basic assumption of Marxism according to Gellner (1994) is that civil society is merely humbug; it is a mask which helps conceal the true, negative and dominant nature of the opposing state to some extent. So basically, both state and civil society are unnecessary. When exploitation realised by the state ceases, a social order arises in which there is no need for institutions to compensate for the central authority (i.e., civil society) either.

According to Anheier, Glasius and Kaldor (2001), the modern approach of civil society was first described by Gramsci (1974). Although his work (Prison Notebooks) does not firstly analyse civil society and is also loaded with inherent contradictions, it still isolates civil society from economic relations. So here we can find civil society in its present-day interpretation between the state and market. At the same time, he says that civil society as a non-state and non-economic stage for social contact is only temporary and strategic, an instrument of the revolutionary struggle. Upon arriving to the ultimate goal, a Marxist world without state and civil society would arise.

The above theories have basically dealt with the formation of civil society, but they still make important deductions from the point of view of this study of co-operation gaps between civil organisations.

The first step in the formation of civil society was the separation of state and civil society. The separation of these two is important in order for the latter to be able to function as a control next to the state and to ensure democracy. Co-operation, on the other hand, is important because these institutions nourish one another - they serve as sources of finances and legitimacy for each other.

The second step was the separation of the economy (market) and civil society. For civil society, its own identity and ability to distinguish itself from profit-oriented and individualistic values represented by the market is important, so undertaking co-operation or any kind of community with the market seems unfeasible.

Ideally, the co-operation of the quartet of the market, state, civil sphere and informal sector, which can be found where their interests intersect, is based upon their distinguishing themselves from each other, while seeing the advantages and strengths of the others, acknowledging them, and co-operating in order to reach a common aim (an integrated, well-functioning, productive society). The economy offers its effectiveness and resources, the state regulates and provides resources, while the civil and informal sectors contribute to the "establishing of the practice and ideology of social compromise and 
reconciliation with its flexibility, its closeness to the individuals forming society and its power to create a community" (Hankiss 2010).

The essence of the first theory-group is that the separation of economy, politics and society has already happened. Thus, we have to consider civil society and initiatives with respect to this threefold unit. This also means that neither can operate without the others, as every one of the three units has an impact on the others, and when analysing one of them one cannot disregard the other two. Their co-operation, therefore - as they "emerged from each other" - is (would be) inevitable in an integrated, well-functioning society.

Another important thing, noted by Gramsci, is that the civil sphere is the stage for social contacts; so if these contacts do not work here, within the civil sector, how can we expect them to work within other sectors, and how can we expect an integrated society?

Having provided an exposition of the above theoretical motive system No. 1, I now review the practical reasons related to these theories for the deficiencies of co-operation between civil organisations that I have revealed.

My PhD study deals with the relationships, co-operations and networks of civil organisations in two regions (Western Transdanubia and the Northern Plain). I review the relationship among these aspects and how they affect the innovative capacity of the organisation, and furthermore, how they influence the success of the region. Semi-structured interviews with the executives of ten civil organisations conducted in May and June 2009 served as good preresearch for investigating this topic. The interviews served as a basis for the shaping of my subsequent questionnaire. The interviews were made in the region of Western Transdanubia, mostly in Györ (seven interviews). The other interviews were conducted in Sopron, Beled and Szombathely. There were interviews with social, environmental, settlement development, health care and interest protection organisations, among others. I did not choose the organisations according to their legal form - there were foundations and associations among them, as well as initiatives related to institutions - or those starting from a real community. So in these interviews, the practical reasons which show why today's civil organisations in Hungary do not like to co-operate can be separated - although they are not representative. The interviews were completed through participation and observation in the Civil Forum held at Győr, which was originally initiated nationwide.

One of the important practical aspects of revealing deficiencies in cooperation is identifying which sector the given organisation belongs to. The intensity of the professional relations of environmental organisations is determined based on the activity fields of the organisations. They are prominent with their strong networking role among the other organisations. 
They are also the ones who do not take part in other umbrella organisations but only in professional ones, and it is they who are able to apply strong pressure during the decision-making process. Their co-operation is probably based on non-interference with the activities of organisations with similar interests: "everybody has enough to do". In other places, however, "there is a fistfight going on" over making a living, and for the clients among the organisations with similar activities (from an interview with the Association of Village Caretakers in Györ-Moson-Sopron and Vas County). On the other hand, cooperation amongst organisations who undertake other kind of activities is easier. Here, cooperation behaviour is mainly confined to organising events together (Kolping Family Association, Szombathely).

Another important aspect is the size of the given organisation. The willingness to co-operate among the "bigger" organisations ${ }^{3}$ is low or non-existent. We can probably eliminate financial interests or service demands as a reason for this non-co-operation, which is not typical for big organisations. These organisations are the ones that form their networks on their own and co-operate with organisations established by them (from an interview with the Kolping Family Association, Szombathely). In other words, they may duplicate the organisation in order to have greater weight and to be able to lobby in the interests of the realisation of their own goals, and accordingly, of being able to secure more resources. Networking between these organisations is therefore strong, although they do not seek external relations first and foremost, but rather establish co-operating organisations on their own. The weak relations referred to by Granovetter are hardly present at all here, so the viability of these networks is disputable as well without the establishing organisation. According to the research of Bartal, Kákai and Szabó (2005), establishing relations between non-profit organisations and national non-profit organisations is mostly dominated by relations of reconciling interests, and the least characteristic relation is a supportive one (Kákai 2005).

So, in linking my interviewees' experiences to the first group of theories, I think we can see that, although the civil sector should have been separated from the market and state in Hungary, and should have had independence, its working mechanism is very similar to the market and to the state. It is based on the organisations' size, viability and interest. The role of human contacts and common will is less important at the moment, and this sector is currently operating in a very similar way to the market (call it a 'civil market', if you

3 I understand the term "bigger organisation" to mean organisations with nationwide power and/ or with a turnover of at least 50 million HUF per year. 
like), which is a very important point to understand when considering the collaboration gap of the civil sphere.

Distrust is intensified by the race amongst organisations for the very limited resources described by many at various times (Kákai 2005, Bartal 2005, Sebestény 2005 and 2009), which only sharpens the conflict of interests. During my interviews, several organisations clearly stated that they are not ready to share their resources with others, even if the income would be expected to increase based on acting co-operatively. The reason is that the amount of administrative work and energy invested in the cooperation is not in proportion to the prospectively bigger income (Pannónia Association for Equal Rights, Győr). At the same time, a problem which often arises in the non-profit field is that a consortium co-operation built through tenders as a co-operative driving force mostly does not support the establishment and sustaining of relations and networking between civil organisations. The reason for this is that if an organisation enters the tender process on its own, it will possibly have a somewhat smaller income, but basically it can still gain more resources than when it has to share support with a consortium partner. Therefore the incentive to co-operate is not stimulated: it does not equate to more financial resources for the civil organisation. Some organisations only organise as pretence, establishing co-operations which only exist in documents, and thus do not support the development of the cooperation.

Thus, in my own interviews (2009), several organisations indicated as a barrier to co-operation the fact that they never consider involving their organizations in co-operations, either in a civil-state or in a civil-civil relationship. In their opinion, vertical co-operations can be observed primarily where the key factors are the size and type of the organisation. Moreover, bigger organisations dominate during co-operation, or if cooperation happens with a state organisation, the civil organisation is oppressed due to its financial dependence. When considering co-operation between two civils, the willingness to co-operate grows in inverse proportion to the size of the organisation. If, on the other hand, co-operation concerns local government and a civil organisation, a more equal partnership is characteristic.

However, according to my own observations (Civil Fórum, Győr, 27 May 2009), many organisations experience a basic problem, which is that how they define themselves and their goals is doubtful: they regard themselves as autonomous civil organisations - yet they expect help from the state. They build on the paternalist care of the state, but feel it should not interfere in their operations. Thus, there is a fundamental paradox regarding the expectations and interests of co-operating organisations in such given situations. 
All this is consistent with the aforementioned first group of theories. Neither the state nor the civil organisation realizes that their separation is important, but they have to find contact points because their goals are basically the same. They do not understand how they can complete each others' activities, and this is a severe barrier to co-operation.

The serious finding from my interviews is that consideration of the possibility of co-operation with market organisations has not even occurred. If we say that co-operations with state / local government may meet with difficulties, then market-civil co-operations are not even mentioned. As my interviewee from Szombathely put it, "a civil organisation cannot offer anything valuable or important to entrepreneurs in return for support, and one has to carry out so much administration for such a little amount of money that it's not worth it" (Kolping Family Association, Szombathely).

The basis of every good collaboration (mentioned in any context) is that the partners have a solid self-identity, can realize their limits of competency and recognize the knowledge, values and skills of others.

I think that in Hungary the market, state and civil sector cannot realize their limits of competency, cannot recognise the knowledge, values and skills of others, and, for the most part, the civil sphere does not have a solid selfidentity at the moment - although we think that the separation of economic, political and social spheres has occurred.

\section{MOTIVE SYSTEM NO. 2: THE RELATIONSHIP BETWEEN COMMUNITY (AS THE BASIS OF THE CIVIL SECTOR) AND SOCIETY}

The second explanation for the reasons for deficiencies in co-operation is provided by theories dealing with the relationship between community (as the basis of the civil sector) and society.

According to Weber's theory (1976), structural forms of community actions are autonomous; so many kinds of motives can play a role in establishing a community, and not only those limited to economic motivation. According to Weber - although he does not explicitly talk about civil society - one of the first signs of establishing a community is community action, which then transforms the community into an association or a civil organisation. However, a shared interest is needed for this, which is usually the economy, but of course it can be something else (e.g., a special interest group) as well. Weber (1992) sets two basic conditions for community: it consists of people who belong together on a special basis and who are connected by a common 
action. He also reckons faith in kinship as being an important communitybuilding force, which is based on the fact that "all of them are involved in a specific 'honour' which outsiders do not have at disposal" (Weber 1992, 46).

On the other hand, according to the theory, common interests belonging merely to the 'intellectual life' of the community are not as effective as economic interests are. Therefore, "systematically working, rational operation takes the place of temporary, irrational and occasional actions. The former operates further on even if the people involved had long before lost their enthusiasm for these ideas" (Weber 1976, 43). It is therefore obvious that Weber admits to the functioning of civil society, although he does not think it to be as effective as the economy is. He also draws attention to the reason for the 'dying off' of the units of civil society, which is a loss of motivation.

Primarily, it is Tönnies (1983) who deals with the issue of community and society by contrasting the two. He says that community is an intimate living together, while society is public. He considers community a living organisation and society a mechanical, artificial formation. He looks on community life as providing mutual possessions and benefits; that is, the possessions and benefits of common goods.

According to Tönnies, there are three binding elements in a community: blood (relation, network), place (geographical determination of language and culture) and consciousness (remembering and recollection).

In the opinion of Csepeli (1981), on the other hand, there are several possible definitions for a community, including a place where social human beings concentrate, held together by goals and demands, characterised by attitudes and norms, which support the development of its members, characterised by consciousness and improvement. He sees their significance in offering goals and a perspective for the individual, and in providing an experience of belonging.

Mérei (1971) reminds us that the really important issue is the spontaneous network of these communities, which is always there in the background, even if it is not stabilised as an institutional network.

In Hankiss's interpretation (1983), the system of vertical relations within communities is more important than the aforementioned horizontal connections. Vertical relations signal dependencies. According to Hankiss, different layers of society are connected by personal and not by institutional relations, although both appear often parallel with each other. The crucial relations in the system are vertical and not horizontal. Hankiss says that communities of a vertical character are determinant because establishing communities of a horizontal nature meets intense resistance from society. Since horizontal communities are recruited from individuals of the same 
level of social hierarchy, where social differences do not play a role, society tolerates them in turn with difficulty only. ${ }^{4}$

Hankiss also says in his work 'New Diagnosis', from 2002, that the establishment of community dialogues and networks remains a daydream.

To sum up the moral of this group of theories, we can state that in the formation of civil society, what turns out to be important is not only its separation from the economy and state, but also its separation from the informal sector - which stands as mentioned above at the point of intersection of the economy, state and civil society - or from the community, to rephrase. However, community plays an important role as regards the topic, because civil organisations are set up from informal communities, and so are organised from below. In conclusion, something that indicates a deficiency in cooperation between communities or the individuals in them also appears in the co-operation of civil organisations. Hankiss's theory above underlines the fact that different levels of society - and therefore also of the civil organisations or informal communities - are connected primarily by personal relationships (or in Gramsci's theory, they are the primary figures in the social contact). With my approach, one of the reasons for the gaps in co-operation between civil organisations is to be found in this aspect. Personal relationships, personal sympathies and personal interests are decisive, and because an organisation or community stands also for the individual, latent, individual problems manifest here.

The community is not only determined from the point of view of interests and personality, but also in consideration of the fact that another community embodies another culture, which also determines willingness to co-operate.

Habermas (1965) traces civil society back from the idea of bourgeois publicity and analyses the cultures of each country one by one (another community, another culture) according to the formation of the little circles of publicity. In his theory, it is culture that dominates and not separate subsystems (economy, politics, civil society), nor even the community-society relationship.

The theory of A. Gergely András (1993) synthesises the notions of community, society and culture. According to him, community has connected family, relatives, possessions, roles and obligations, and locality exists only in the relation-system of belonging to a macro-society.

Local societies are none other than processes of multidimensional social organisations in which the common goal- and value-systems, norm order and cultural tradition are determined. We are therefore describing a dual system

4 In contrast to this, Beck (2003) explains that in the new modernity, it is exactly these communities which are getting stronger. 
(local and social) whose inner pillar is their multitude of community- and local power relations and co-operation forms.

Böhm (2003) places the issue of society-community into the relation system of globalism-locality. In his opinion, globalisation disintegrates traditional societies and changes traditional human relationships and values. Parallel with this, however, the process of localisation is occurring. In losing traditional values, the demand for communities is getting stronger in society, as are the efforts to maintain the values and relations of smaller communities.

In local society organisation, civil organisations play an exceptionally important role. In accordance with Böhm's schemata, the starting-point is the family as primary community around which kinship, neighbourhood and other more and more consciously-organising communities are forming to solidify local society. These stages are also the steps of integration. In my own view, however, these steps are not only stages of integration but also of interactions. It is important that the centre point in the theory is the individual, who is not a passive spectator but who forms their own behaviour pattern actively in the different areas of their environment. Bőhm's theory fits with the human eco-system approach (Gordon and Schutz 1982), in the centre of which there is the individual, with the emphasis on the two-way interaction between the individual and their environment encircling them in the manner of an onion (family, local community, culture, nation, state, society). Bőhm says that the democratisation of big society and transmitting mechanisms, as well as production and consumption, public life and communication are of determining importance from the point of view of organising communities. Local societies are able to connect with wider society through these aspects, and society regulates local communities through these. If one of these aspects is damaged, the co-operations which exist in relation to the formal and informal sector, civil-civil, civil-state or civil-market organisations also suffer damage.

In Bőhm's view, we may understand that by forming a community the individual participates in - through family, kinship and community forms (to civil community level) - a higher level of organisation, where the cohesion of local society is expressed and where its identity-awareness also appears.

Böhm interprets the relationship between individual and local society through six dimensions: 
Table 1: The Relationship between Individual and Local Society

\begin{tabular}{|c|c|}
\hline INDIVIDUAL & LOCAL SOCIETY \\
\hline contentment & participation \\
\hline affection & co-operation \\
\hline perspective & integration \\
\hline
\end{tabular}

Source: Bőhm 2003.

The message of Gordon, Schutz and A. Gergely is that when we are talking about Hungarian civil organisations or the individuals or communities belonging to them, we are also dwelling on some deeper questions of psychology, socio-psychology and social theory, the notions of which appear above in Table 1. If one of these elements suffers damage (as they have been damaged many times in the history of Hungary), the co-operational motivation of civil organisations becomes damaged as well.

The second group of theories, which were brought up previously, deals with the relationship of society and community. It is obvious that the whole society cannot commit itself to single initiatives because society is made up of individuals who have different values, goals and interests, and even different cultures. Therefore, it is necessary to split up society into groups of individuals with identical values and goals into communities - at least for the purposes of this essay - which are able to start, from their point of view, important civil initiatives. This group of theories, on the other hand, also transmits the message that societies with different values, goals, interests and cultures think about civil initiatives, and obviously civil co-operation, in a different way.

In turning these theories into practice, in my interviews we can see another severe barrier to the formation of adequate partner co-operations, which is that most organisations' willingness to co-operate is person-dependent. They do not decide for or against co-operation on the basis of professional or organisational interests, but the "personal attitude determines the formation of the relation" (ELKE's Treasure Foundation, Sopron), which again suggests unprofessionalism on the one hand and confirms the consequences drawn from the community theories discussed in the theoretical section. 


\section{MOTIVE SYSTEM NO. 3: \\ DIFFERENT TYPES OF CIVIL SOCIETIES ADVANCE IN DIFFERENT TYPES OF SOCIETIES}

The fact that current civil organisations in Hungary are not able to and are not willing to co-operate cannot merely be traced back to the difficulties outlined in the aforementioned theory systems. This also has its roots in the enormous differences between Western and Eastern European countries: "civil society has always been present - at least since 1945 - in the western part of the world, even if it was not set a high value on. Most modern-day social theories consider it - in a comic way - already as given: all of them spring from the individual who is free of all secular, social and religious bands, chooses his own goals and does a deal with their fellows in order to secure social order. Thus they assume civil society as always present, as a substantial ingredient of human relations. And this is the consequence of a defined, special approach, the generalisation of the view that emerged about a certainly lucky type of human being, about the citizen of civil society. In reality, this type of human being is considerably different from others living in other kinds of societies..." (Gellner 1994, 17). "If we want to understand what civil society stands for today, we cannot treat all societies which ever existed alike, in which effective institutions are balancing out state authority" (Gellner, 1994, 14). Gellner outlines three alternatives: firstly, he speaks of societies determined by cast relationships and rituals, in which the will of central power does not necessarily prevail, but does not ensure satisfying freedom either; secondly, he outlines the role of centralised powers which submit everything to centralised control, thereby wiping out social subsystems; and thirdly, he distinguishes the formation that, according to him, can be exclusively viewed as civil society - a form equally free of paternalism and centralisation and based exclusively upon freedom.

Böhm $(1999,2003)$ also points out that the civil sphere in Eastern European countries differs from that of Western Europe. He sees the reasons for this in historical development (traumas of the $20^{\text {th }}$ century, the hindrance of the formation of a modern civilised society), in the geographical situation (half-peripheral situation) and in national mentality (being accustomed to paternalism). Bőhm bases his ideas upon the theories of Erdei, Bibó and Szücs (1983). According to Szücs - who builds upon the ideas of Bibó - certain structures are important behind the "occurrences" which set boundaries and possibilities for the present.

Szücs says that Western development goes back to the circumstances around its genesis, and can be understood through contrast with other civilisations 
(e.g., the ancient form of civil society must have originated from a feudal context, but this is solely possible because history had previously set the scene for the feudal relation to the state).

For the birth of the West, disintegration was an important requirement:

1. Disintegration by overcoming the deadlock of high culture by breaking down local frames and agrarian relations,

2. breaking down political sovereignty with the birth of the autonomous city,

3. the intensity of dense city networks and exchanges of goods.

According to Bibó and Szücs, the West is consequently characterised by the symbolism of motion, and the East by the symbolism of motionlessness.

"The stability of the West, which is in its basic elements disintegrated, was secured in the long run by the fact that it could not have been integrated "from above". The lines of force of integration started to unfold "from below"5 (Szücs 1983, 28).

The West has integrated all the elements of society into the system by vassalage, and this has not taken a place next to or under the state, but has taken the place of it. ${ }^{6}$

Or, rephrased: "the multitude of little circles of freedom" (Bibó, referred to by Szücs 1983 , 40) delineates the West from many other civilizations and helped with the formation of the autonomous notion of society.

In the East, on the other hand, the church, the nobility, the peasantry and the bourgeoisie of the cities were subordinated to regal power, which excluded any kind of corporate unity. The characteristics of the East are the cumulative, inarticulate rapidity of development and disproportionate realignment from above.

In the West, the inner principles of arrangement dominated the state, while in the East, reforms targeted the formation of basic elements of the structure (e.g., settling, serf reforms). The lagging of the "East" also manifested in certain passive elements: the Hungarian language entered literacy with a lag of three centuries; a disproportionately broad nobility emerged; it took over the "county" as an early feudal frame of regionalism without any feudal transfer and in doing so blocked the flow of local legality from bottom to top; it was characterised by mutuality of unequal "players", by a missing contractual aspect and by a servile character; in the market towns the way of life was rather peasant and bourgeois, and an uneducated but privileged lower gentry appeared.

5 Szűcs, J. (1983), Vázlat Európa három történeti régiójáról Magvető Kiadó, Bp., 28.o.

6 See the notion of social contract in the ideas of Hobbes. 
According to Anderson, the absolute monarchy in the West was compensation for the dissolution of the peasantry, and in the East it was an instrument for the peasantry's solidification. The West subordinated society to the state while the East secularized it. In the East nobody carried out a national reformation, and that resulted in passivity and submission to things, because until then every important issue was decided at the highest level. The two outer regions of Europe (the West and the East) have undertaken their revolutions, while Hungary, on the other hand, could only produce failing half-revolutions. ${ }^{7}$

All this was accompanied by the factors of the socialist period revealed by Hankiss (1989).

According to Hankiss (1989), the demolition of economic and social actors in socialist Hungary was based on the following factors:

- secularisation of industrial and trade companies,

- liquidation of the capital market and of the free flow of capital,

- collectivisation of agriculture,

- centralisation of decision making,

- limitation of the autonomy of churches,

- disciplining of the work force,

- cutting off at the root - sudden mobility (from a worker to a manager overnight)

- elimination of the autonomy of independent craftsman and retailers,

- elimination of the representation of interests for different professions and of the Court of Administration,

- secularisation of unions,

- elimination of National Committees,

- systems of soviets,

- indoctrination (collective interest),

- elimination of independent mass organisations (i.e., elimination of "forerunners" civil society and sector - remark by the author),

- atomisation and clientisation of society (depriving it of social organisations and networks, wedging people into the functions of family and private life),

- destruction of social identities (on the micro-level, parentage was stigmatized; on a meso- and macro-level, the elimination of social groups, networks and associations, transforming the sense of class into a sense of guilt: peasant $=$ kulak, worker $=$ lumpenproletar).

The following table provides a summary of the ideas of the above authors.

7 The little circles of freedom could not be fully cut out from here. 
Table 2: Comparison of Western and Eastern Development of Society

\begin{tabular}{|c|c|c|}
\hline ASPECTS & WEST & EAST \\
\hline Historic development & $\begin{array}{c}\text { free of traumas, the "good" } \\
\text { side }\end{array}$ & $\begin{array}{l}\text { loaded with traumas, the } \\
\text { "bad" side }\end{array}$ \\
\hline Social development & bourgeois civilization & $\begin{array}{l}\text { hindrance of bourgeois } \\
\text { civilization }\end{array}$ \\
\hline Geographical situation & central & half-peripheral \\
\hline Characteristic rhythm & motion, activity & motionlessness, passivity \\
\hline Force line of integration & from below & from above \\
\hline $\begin{array}{c}\text { Dominant arranging } \\
\text { principle }\end{array}$ & society & state \\
\hline $\begin{array}{l}\text { Relationship between state } \\
\text { and society }\end{array}$ & contract & power \\
\hline $\begin{array}{l}\text { Economic arranging } \\
\text { principle }\end{array}$ & free flow of capital & secularisation \\
\hline Identity & importance of roots, locality & cutting of roots, atomisation \\
\hline Citizens & $\begin{array}{l}\text { individual persons, a } \\
\text { civilian of the state }\end{array}$ & client \\
\hline
\end{tabular}

Source: Author's own summary based on the studies of Bőhm, Erdei, Bibó, Szűcs and Hankiss.

The third group of theories is built up from ideas regarding the development of society in the West and the East. As my essay basically deals with the networks, relationships and co-operations of civil initiatives in respect to Hungary, these ideas are of great importance. I think these lead to a deeper understanding of the problem, as the forming of civil society, the functioning (or ill-functioning) of its relations, and the ad-hoc characteristics of its cooperation (Nárai 2007) can be traced back in one respect to the differences in the development of society. By contrasting the characteristics of West and the East (see Table 2 above), it is obvious that the distrust of other individuals, organisations, systems, etc. were embedded into the development of the East (i.e., in Hungary), so the basis for organisation and co-operation based upon and built on joining forces (see civil organisations and initiatives) is missing in Hungary.

In practice, as I saw in my interviews, another sign of unprofessionalism and the lack of organisation is that informational channels do not exist amongst 
organisations. Not only do organisations not know each other, but they do not use opportunities (e.g., the Internet, forums and flyers) to introduce themselves and to get to know each other. Often there is no demand for getting in contact with others at all; the organisation separates itself in advance from the rest of the sphere. One reason we cannot give for this is the different kind of social development in Hungary and Western countries, as this reason was not generated from the interviews with the organisations. There were only statements regarding the historic past in regard to one organisation (ELKE's Treasure Foundation, Sopron). According to the leader of this organisation, the past clearly obstructs present co-operation: "This whole thing does not work because this great neo-liberalism was poured upon the people, who may have been happy about it, but were not prepared for it."

\section{SUMMARY}

As the starting point of my essay I presented the statement that harmony between civil organisations in today's Hungary, which would enable the realisation of broad co-operation (Kákai 2005) - either in a civil-civil relation or as co-operations between sectors - is insufficient. This statement is supported and justified both theoretically and in practice by a multilayer system of motives.

On the one hand, as I mentioned, the separation of economy, politics and society took place through long processes and ran (in the case of politics and economy) so efficiently and independently, that today we tend to forget that they were "born" from each other, and thus their co-operation is inevitable. And it is at the centre of co-operation that the birth and functioning of civil society (should) reside.

Others do not trace back the birth of civil society from the separation of the three sectors, but deal with the relation of society and community. Their message for me is that different communities (civil initiatives, co-operations) exist in different societies according to the values, norms and culture therein, and therefore we cannot treat them in a consistent way.

This approach is complemented by the different developmental trends in the West and East. The theories state that distrust of other individuals, organisations, systems, etc., were embedded in the development of the East (i.e., in Hungary), so the basis for organisations and co-operations based upon and built on joining forces (i.e. civil organisations and initiatives) is missing in Hungary.

In my way of thinking, societal functions have been split apart into sectors. 
We can also separate practical reasons from theoretical reasons for cultures, value systems and norms based on different kinds of social development, which affect the establishment of a culture of civil co-operation in a negative way.

Practical factors acting against co-operation are in proportion to the size of civil organisations on the one hand, and with their type on the other hand. Generally, we can say that the bigger the organisation is, the less its willingness is to co-operate, as it finds no interests satisfied in cooperating. Most cooperating organisations have a financial interest in co-operation, but often this is no longer a reason. The consortium postulate built into the tendering system for civil organisations as a motivating factor primarily has a demotivating effect because co-operations often only exist on paper and the tender system pits organisations striving for the same goal into competitive situations.

Another factor acting against co-operation is that many organisations cannot even define themselves, are not aware of their own goals and trends and do not utilise any kinds of strategy or technique for introducing their own organisations and have no information about other organisations with similar pursuits, some of whom could probably be co-operation partners for them.

Last but not least, I consider the biggest practical problem to be the fact that co-operations are almost always person-dependent. The role and use of knowledge management as a driving force for co-operation with others and making progress by doing so does not even occur to civil organisations.

Based on all these problems and "encoded" and determined reasons for the development of society, we can understand the lack of co-operation in the civil sphere, which also draws attention to the fact that the lack of cooperation signals basic social problems.

"In fact, solidarity with society equates with (...) aid distribution in the case of trouble, rather than as an advertising act or as light affection of people for society and for each other. This is, by the way, to be seen in many places in many forms" (ELKE's Treasure Foundation, Sopron). 


\section{REFERENCES}

A. Gergely, A. (1993) Urbanizált méhkas, avagy a helyi társadalom (Urbanized Beehive, or the Local Society) MTA Politikai Tudományok Intézete, Budapest

Anheier, H. - Glasius, M. - Kaldor, M. (2001) A globális civil társadalom bemutatása (An Introduction to the Global Civil Society) in: Anheier, H. - Glasius, M. - Kaldor, M. (szerk.) Globális civil társadalom I. Typotex, Budapest

Bartal, A. M. - Kákai L. - Szabó I. (2005): A nonprofit szervezetek érdekképviselete, kapcsolatrendszere (Representation of Interests and Network of Relations of NonProfit Organisations) Századvég Civil Akadémia, Budapest

Beck, U. (2003) A kockázat- társadalom Út egy másik modernitásba (Risk Society: Towards a New Modernity) Andorka Rudolf Társadalomtudományi Társaság Századvég Kiadó, Budapest

Bőhm, A. (2003) Az ezredvég magyar társadalma, Folyamatosság és megszakitottság a társadalomfejlödésben (Hungarian Society at the End of the Millennium, Continuity and Discontinuity in the Development of Society) Rejtjel Kiadó, Budapest

Csányi, V. (1999) Az emberi természet, Humánetológia (Human Nature, Humanethology) Vince Kiadó, Bp.

Csepeli, Gy. (1981) Közösség és társadalomtudomány (Community and Social Science), in: Tibori, T. - T. Kiss, T. (2000) Közösségi formációk Új Mandátum Könyvkiadó, SZIE JFK, Budapest, p. 80-85.

Farkas, J. L. (2007) Civil filozófia: Hobbes (Civil Philosophy: Hobbes) www. nyitottegyetem.phil-inst.hu/Tarsfil/fj_2_el.htm, letöltve: 2008.01. 16.

Gellner, E. (1994) A szabadság feltételei (Conditions of Liberty) Typotex, Budapest

Glózer, R. (1999) Nyugat-európai várakozások a kelet-európai rendszerváltások kapcsán (Expectations in Western Europe Regarding the Regime Changes in Eastern Europe), in: Magyar és európai civil társadalom szerk: Csefkó, F. Horváth, Cs. (1999) MTA RKK Dunántúli Tudományos Intézete - Pécs-Baranyai Értelmiségi Egyesület, Pécs, 71-75.o.

Glózer, R. (2008) Diskurzusok a civil társadalomról (Discourses about Civil Society) L'Harmattan, Budapest

Gramsci, A. (1974) Levelek a börtönböl (Prison Notebooks) Kossuth Könyvkiadó, Budapest

Hankiss, E. (1983) Társadalmi csapdák-Diagnózisok (Traps of Society-Diagnoses), in: Tibori, T. - T. Kiss, T. (2000) Közösségi formációk Új Mandátum Könyvkiadó, SZIE JFK, Budapest, p. 90-100.

Hankiss, E. (2002) Új Diagnózisok (New Diagnoses) Osiris Kiadó, Budapest

Hankiss, E. (1989) Kelet-európai alternatívák (Alternatives in Eastern Europe) Közgazdasági és Jogi Könyvkiadó, Bp

Hankiss, E. (2010) Szedett-vedett ország? Egy igazi társadalmi szerzödés (A Patchy Country? A Real Social Contract) HVG, 2010. július 13.

Hegel, G.W.F. (1977) Elöadások a filozófia történetéröl (Lectures on the History of Philosophy) Akadémiai Kiadó, Budapest 
Hobbes, T. (1970) Leviatán vagy Az egyházi és világi állam formája és hatalma (Leviathan, or the Matter, Forme, and Power of a Commonwealth, Ecclesiasticall and Civil) Magyar Helikon, Budapest

Kákai, L. (2005) Szükséges-e civil összefogás Magyarországon? (Is Civil Co-Operation Necessary in Hungary?) Soros Alapítvány, Budapest

„Kútfó-közösségi innovációs, tudás, információs és tanácsadó hálózat” Igényfelmérö kutatás. (Kútfö - Community Innovation, Knowledge, Information and Consulting Network" Demand Survey) BFH, Szombathely, 2006.

Marx, K. (1962) Marx és Engels müvei 1844-46 (The Works of Marx and Engels 1844-46) Kossuth Könyvkiadó, Budapest

Mérei, F. (1971) Közösségek rejtett hálózata (The Hidden Network of Communities), in: Tibori, T. - T. Kiss, T. (2000) Közösségi formációk Új Mandátum Könyvkiadó, SZIE JFK, Budapest, p. 85-90.

Miszlivetz, F. (2001) Közép-Európa a kapuk elött (Central Europe Before the Gates) Savaria University Press, Szombathely

Nárai, M. (2007) A nonprofit szervezetek helye és szerepe a helyi társadalmak életében (The Place and Role of Non-Profit Organisations in the Life of Local Societies) Doktori Értekezés, Budapest

Szücs, J. (1983) Vázlat Európa három történeti régiójáról (Draft of Three Historical Regions of Europe) Magvető Kiadó, Bp.

Tönnies, F. (1983) Közösség és társadalom (Community and Civil Society), in: Tibori, T. - T. Kiss, T. (2000) Közösségi formációk Új Mandátum Könyvkiadó, SZIE JFK, Budapest, p. 12-40.

Tóth, G. P. (2002) A „közösség”. Egy fogalom megalkotása, kiteljesedése, széthullása és felszámolása (The "Community". Creation, Perfection, Dissolution and Elimination of a Notion). In: Pócs, É. (2002) Közösség és identitás, L'Harmattan PTE Néprajz Tanszék, Budapest.

Vitairat II. A nonprofit szektor érdekképviseletének megoldása (II. Pamphlet. Solution for the Representation of Interests for the Non-Profit Sector), CIVITALIS Egyesület, Budapest, 2009.

Weber, M. (1992) Gazdaság és társadalom A megértő szociológia alapvonalai (Economy and Society: an outline of interpretive sociology), in: Tibori, T. - T. Kiss, T. (2000) Közösségi formációk Új Mandátum Könyvkiadó, SZIE JFK, Budapest, p. 40-56.

Woods, R. (1996) A szociális munkások tevékenységének egy lehetséges rendszerezése (A Possible System of Social Workers' Function) in: Hegyesi, G. - Talyigás, K. (1996) A szociális munka elmélete és gyakorlata 1. kötet Semmelweis Kiadó, Budapest, pp. 32-46. 